\title{
Investigasi Sebaran Lumpur Panas Menggunakan Metode Geolistrik Tahanan Jenis Konfigurasi Dipol-Dipol di Desa Karumenga Sebagai Mitigasi Bencana Alam
} Febrianti Mangensigaa*, As'aria , Adey Tanaumaa aJurusan Fisika FMIPA Universitas Sam Ratulangi

\begin{tabular}{l} 
K A T A K U N C I \\
\hline Dipol-Dipol \\
Res2dinv \\
Lumpur Panas
\end{tabular}

\begin{abstract}
A B S T R A K
Penelitian ini bertujuan untuk memetakan struktur bawah permukaan di area manifestasi lumpur panas di Desa Karumenga dan menginvestigasi sebaran lumpur panas. Akuisisi data dengan jumlah lintasan 4 yang masing-masing panjang lintasannya yaitu 240 m untuk lintasan 1 dan lintasan 3, 160 m pada lintasan 2, dan $480 \mathrm{~m}$ pada lintasan 4. Data lapangan diukur menggunakan resistivity and IP meter MAE-X612-EM menggunakan metode geolistrik tahanan jenis konfigurasi dipol-dipol. Data pengukuran kemudian diolah menggunakan Software Res2dinv. Hasil berupa model tampang lintang 2D bawah permukaan, lumpur panas diidentifikasi dengan nilai tahanan jenis 13,9 $\Omega \mathrm{m}$ sampai $80 \Omega \mathrm{m}$. Pada lintasan 1 lumpur panas terdapat di sepanjang lintasan dengan kedalaman bervariasi antara 0 sampai 32,5 m. Lintasan 2 lumpur panas terdapat di sepanjang lintasan dengan kedalaman bervariasi antara 0 sampai $24,5 \mathrm{~m}$. Lintasan 3 lumpur panas terdapat di sepanjang lintasan dengan kedalaman bervariasi antara 0 sampai 33,5 m. Pada lintasan 4 lumpur panas tersebar disepanjang lintasan dengan kedalaman $\leq 32 \mathrm{~m}$. Berdasarkan hasil analisis sebaran lumpur panas, diperoleh informasi tingkat
\end{abstract} kerawanan daerah penelitian dengan menggunakan Software Surfer 11.

K E Y W O R D S

Dipole-Dipole

Res2dinv

Hot Mud

\begin{abstract}
A B S T R A C T
This study aims to map subsurface structures in the area of hot mud manifestations in Karumenga Village and investigate the distribution of hot mud. Data acquisition with the number of lines 4 with a length of $240 \mathrm{~m}$ for line 1 and line 3, $160 \mathrm{~m}$ for line 2, and $480 \mathrm{~m}$ for line 4 . Field data were measured using a resistivity and IP meter MAE-X612-EM using the dipole-dipole configuration resistivity geoelectric method. The measurement. Data is processed using Res2dinv Software. The results are in the form of 2D subsurface models, hot mud identified with resistivity values of 13.9 to $80 \Omega \mathrm{m}$. Line 1 , the hot mud is present along the line with depths ranging from 0 to $32.5 \mathrm{~m}$. Line 2, hot mud is appear along the line with depths varying from 0 to $24.5 \mathrm{~m}$. Line 3 , hot mud is located along the line with depths varying from 0 to $33.5 \mathrm{~m}$. Line 4 , hot mud is spread along the line with a depth of $\leq 32 \mathrm{~m}$. Based on the analysis of the hot mud distribution, it is obtained information on the level of vulnerability of the study area by using Surfer 11 Software.
\end{abstract}

TERSEDIA ONLINE

01 Februari 2020

\section{Pendahuluan}

Indonesia tercatat sebagai salah satu wilayah yang sering terjadi bencana alam dan menyebabkan kerugian baik secara infrakstruktur, lingkungan hidup ataupun trauma bagi masyarakat. Terjadinya bencana alam dapat disebabkan oleh alam itu sendiri atau juga karena aktivitas manusia. Untuk itu setiap kelompok masyarakat seharusnya mempunyai pengetahuan dan cara untuk menghadapi lingkungan demi kelangsungan hidupnya. Pengetahuan dan cara ini dikenal sebagai "wisdom to cope with the local events" atau sering disingkat dengan istilah "local wisdom" yaitu kebijaksanaan untuk mengatasi suatu peristiwa lokal (Maarif dkk., 2012). Pemerintah dalam Undang-Undang Nomor 24 Tahun 2007 juga mengatur tentang penanggulangan bencana dengan tujuan mengurangi resiko dampak bencana alam. Pengelolaan bencana di Indonesia yang dahulu lebih 
bersifat responsif atau tanggap darurat dalam menangani bencana, sekarang diubah menjadi suatu kegiatan mitigasi bencana dimana resikonya dapat diminimalisir (Faturahman, 2018). Untuk itu penelitian dalam meminimalisir dampak dari berbagai bencana, baik itu bencana yang terjadi karena aktivitas manusia maupun bencana alam, perlu dilakukan di seluruh wilayah Indonesia.

Wilayah Indonesia memiliki potensi energi panas bumi yang diperkirakan mencapai $40 \%$ dari total cadangan energi panas bumi dunia sebagaimana Indonesia secara geografis terletak di sepanjang "Ring of Fire" atau cincin api dimana sebagian besar gunung berapi ada (Saptadji, 2010). Adanya energi panas bumi dapat dilihat dari kemunculannya dipermukaan sebagai manifestasi air panas, fumarole, geyser, tanah hangat/beruap dan lumpur panas (Ebrahimi dkk., 2019). Lumpur panas merupakan manifestasi dari energi panas bumi yang muncul ke permukaan umumnya mengandung uap panas yang tidak terlalu banyak dan tidak mengeluarkan gas hidrokarbon (metana dan asam sulfida) (Pratama dkk., 2019). Terdapat dua jenis manifestasi lumpur yaitu, manifestasi lumpur yang berkaitan dengan adanya aktivitas gunung berapi yang bersuhu tinggi dan manifestasi lumpur yang tidak terkait aktivitas gunung berapi dengan suhu relatif rendah (Wiranata dkk., 2018). Berdasarkan dengan keberadaan manifestasi lumpur panas di dekat area permukiman warga, maka penelitian ini dilakukan untuk memetakkan struktur bawah permukaan di lokasi manifestasi lumpur panas yang berujung sebagai mitigasi bencana alam di Desa Karumenga, Kecamatan Langowan Utara, Kabupaten Minahasa, Sulawesi Utara, seperti terlihat pada Gambar 1.

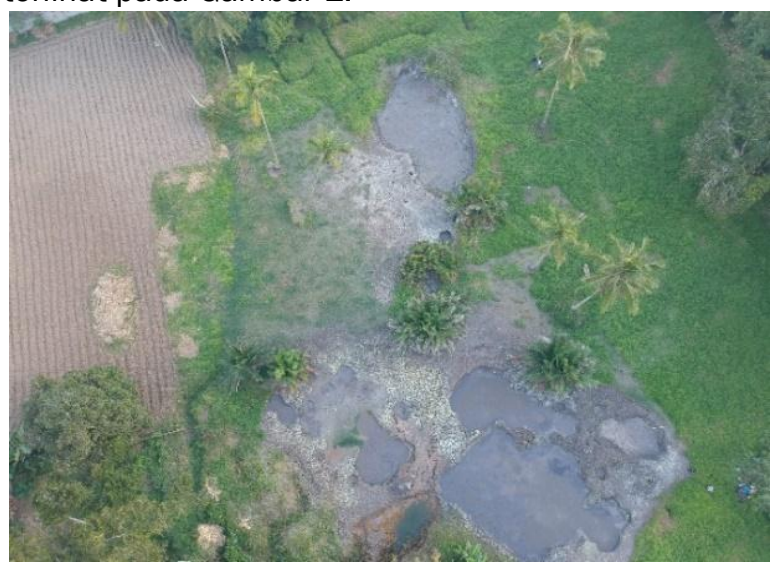

Gambar 1 Manifestasi lumpur panas Desa

Karumenga, Kecamatan Langowan Utara,

Kabupaten Minahasa, Sulawesi Utara.

Eksplorasi metode geolistrik tahanan jenis merupakan eksplorasi geofisika yang ramah lingkungan dan tidak merusak (As'ari dkk., 2017). Metode geolistrik juga merupakan metode yang banyak digunakan untuk memperoleh gambaran mengenai struktur bawah permukaan dan formasi batuan berdasarkan variasi dari nilai resistivitas (Wijaya, 2015). Pendugaan dengan metode geolistrik ini didasarkan pada setiap bahan material yang berbeda akan mempunyai nilai resistivitas yang berbeda apabila dialiri arus listrik. Terdapat beberapa jenis konfigurasi dalam metode geolistrik tahanan jenis seperti konfigurasi Wenner, konfigurasi Schlumberger dan konfigurasi dipoldipol. Konfigurasi dipol-dipol biasanya digunakan karena konfigurasi ini dapat mengambil gambaran bawah permukaan pada objek yang penetrasinya relatif lebih dalam dibandingkan dengan konfigurasi lainnya seperti konfigurasi Wenner atau konfigurasi Schlumberger dan waktu yang dibutuhkan dalam pengambilan data juga lebiih cepat dibandingkan konfigurasi yang lainnya (Basid dkk., 2014).

Keberadaan lumpur panas yang ada harus diketahui sebarannya karena jika sebaran lumpur panas berada di area yang tidak tepat maka akan menimbulkan dampak atau resiko yang membahayakan. Oleh karena itu pemetaan struktur bawah permukaan bumi penting dilakukan untuk menentukan sebaran dari lumpur panas yang muncul ke permukaan tanah (Wildan dan Wahyu, 2015). Penelitian ini menggunakan konfigurasi dipol-dipol dengan 4 lintasan pengukuran.

Material dan Metode Penelitian
Alat - alat yang digunakan dalam penelitian ini
adalah Resistivitymeter (multi-channel resistivity
and IP meter) MAE-X612-EM, GPS (Global
Positioning system), Handy Talkie (HT), Termometer
Infrared, Software Res2dinv, Software Notepad,
Software Surfer 11, dan Laptop Lenovo 110 .
Penelitian ini dilakukan di Desa Karumenga,
Kecamatan Langowan Utara, Kabupaten Minahasa,
Sulawesi Utara pada koordinat (01010'18.57"
sampai 01010'03.36") LU dan (124049'57.51"
sampai 124050 '01.59") BT. Penelitian
menggunakan metode geolistrik tahanan jenis
konfigurasi dipol-dipol menggunakan 4 lintasan
pengukuran dengan panjang lintasan 1 dan lintasan
3 yaitu 240 m dan spasi antar elektroda 5 m,
panjang lintasan 2 yaitu 160 m dengan spasi $5 \mathrm{~m}$,
dan panjang lintasan 4 yaitu 480 m dengan spasi
antar elektroda 10 m (Gambar 2 ).

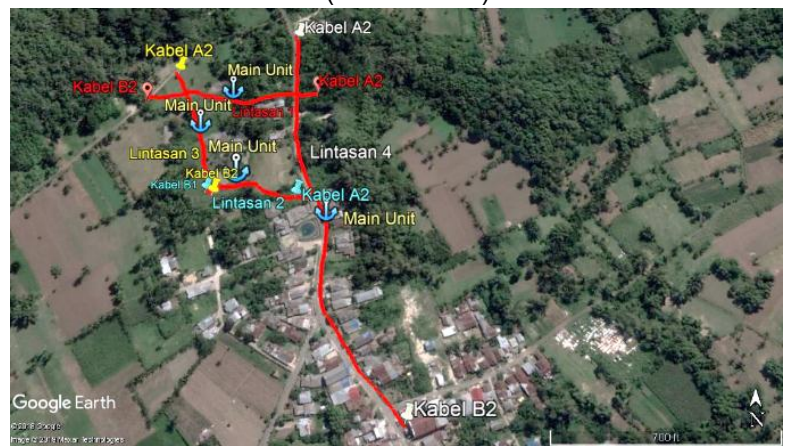

Gambar 2 Lintasan pada lokasi penelitian.

\footnotetext{
Hasil dan Pembahasan

Data yang diperoleh diolah menggunakan Software Res2dinv. Penelitian ini merupakan yang pertama dilakukan di Desa Karumenga. Dari penelitian yang telah dilakukan diperoleh hasil tampang lintang 2D yang kemudian diidentifikasi
} 
sebagai sebaran lumpur panas yang ada di bawah permukaan lokasi penelitian.

Pada lintasan 1, jalur lintasan pengukuran melewati satu rumah warga, perkebunan yang ditanami jagung, daun bawang dan ubi (singkong, talas). Jalur lintasan 1 pada elektroda ke 22, 23, 26, dan 27 terdapat manifestasi lumpur panas yang berjarak $\pm 2 \mathrm{~m}$ dari bentangan kabel. Dari hasil pengolahan data pada lintasan (Gambar 3) lumpur panas mendominasi disepanjang jalur lintasan dengan nilai resistivitas 13,9 - $80 \Omega$ m dengan citra warna hijau hingga kuning. Lumpur panas pada lintasan 1 tersebar di sepanjang jalur lintasan dengan kedalaman bervariasi antara 0 sampai 32,5 $\mathrm{m}$.

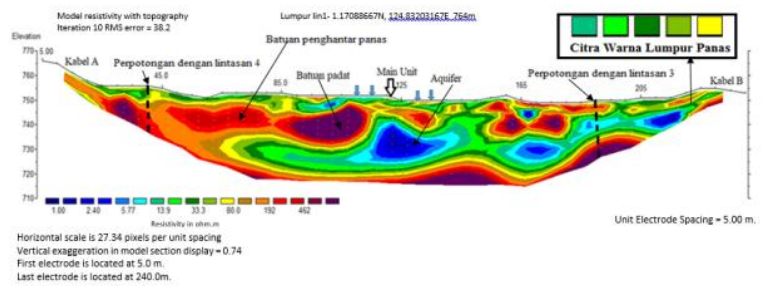

Gambar 3 Hasil identifikasi lintasan 1.

Pada lintasan 2, jalur lintasan pengukuran melewati satu rumah dan kebun jagung. Jalur lintasan 2 pada ke elektroda 21, 22 dan 23 terdapat manifestasi lumpur panas yang berjarak \pm $2 \mathrm{~m}$ dari bentangan kabel. Dari hasil pengolahan data pada lintasan 2 (Gambar 4) lumpur panas mendominasi disepanjang jalur lintasan dengan nilai resistivitas 13,9 - $80 \Omega \mathrm{m}$ dengan citra warna hijau hingga kuning. Lumpur panas pada lintasan 2 tersebar di sepanjang jalur lintasan dengan kedalaman bervariasi antara 0 sampai 24,5 m.

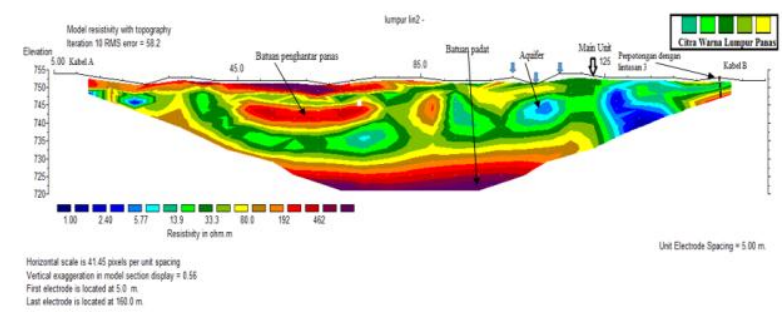

Gambar 4 Hasil identifikasi lintasan 2.

Pada lintasan 3, jalur lintasan pengukuran melewati lahan kosong untuk perkebunan yang belum ditanami tanaman sekitar $30 \mathrm{~m}$ panjang lintasan. Jalur lintasan 1 pada elektroda ke 12 terdapat manifestasi lumpur panas seperti sumur kecil dengan kedalaman $\pm 2-3 \mathrm{~m}$. Manifestasi lumpur panas juga berhadapan dengan elektroda 17, 18 dan 19 di titik ini lumpur panas tertutupi oleh semak sekitar 3 m. Kemudian elektroda 26, 27, 28 dan elektroda 40, 41, 42 berhadapan dengan manifestasi lumpur panas. Jalur lintasan 3 merupakan titik terbesar manifestasi lumpur panas. Dari hasil pengolahan data pada lintasan 3 (Gambar 5) lumpur panas mendominasi disepanjang jalur lintasan dengan nilai resistivitas 13,9 - $80 \Omega \mathrm{m}$ dengan citra warna hijau hingga kuning. Lumpur panas pada lintasan 3 tersebar di sepanjang jalur lintasan dengan kedalaman bervariasi antara 0 sampai 33,5 $\mathrm{m}$.

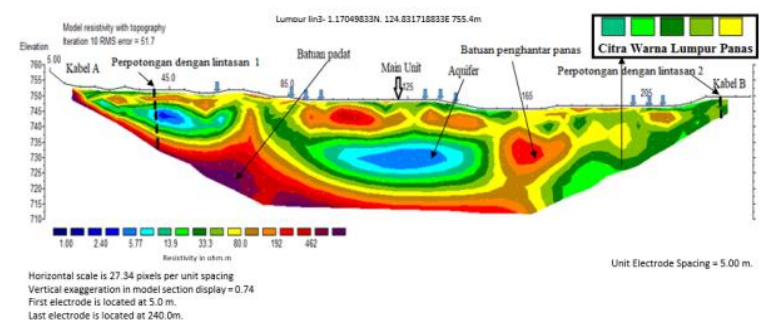

Gambar 5 Hasil identifikasi lintasan 3.

Pada lintasan 4, jalur lintasan pengukuran melewati pemukiman warga. Jalur lintasan 4 pada elektroda 1, 2, dan 3 dekat dengan tebing dengan tinggi mencapai $\pm 20 \mathrm{~m}$. Pada elektroda 16 dan 17 juga terdapat tebing yang mencapai $\pm 15 \mathrm{~m}$. Elektroda 24 dan 25 tepat berhadapan dengan kolam air panas dan pada elektroda 36 dan 37 terdapat manifestasi lumpur panas berupa sumur. Jarak dari elektroda dengan sumur $\pm 1 \mathrm{~m}$ dengan kedalaman sumur mencapai $\pm 5-7 \mathrm{~m}$. Dari hasil pengolahan data pada lintasan 4 (Gambar 6) diidentifikasi sebaran lumpur panas dengan nilai resistivitas 13,9 - $80 \Omega$ m yang ditandai citra warna hijau hingga kuning hanya berada dibeberapa bagian jalur lintasan dengan kedalaman yang bervariasi. Bagian pertama terdapat pada meter ke 60 sampai meter ke 75 dengan kedalaman 4 sampai $11 \mathrm{~m}$. Bagian ke dua terdapat pada meter ke 89 sampai 148 dengan kedalaman bervariasi antara 0 sampai $9,5 \mathrm{~m}$. Bagian ke tiga terdapat pada meter ke 150 sampai meter ke 165 dengan kedalaman 5 sampai $14 \mathrm{~m}$. Bagian ke empat terdapat pada meter ke 190 sampai meter ke 201 dengan kedalaman bervariasi antara 4,5 m sampai $20,5 \mathrm{~m}$. Bagian ke lima terdapat pada meter ke 205 sampai meter ke 230 dengan kedalaman bervariasi dari 0 sampai $6 \mathrm{~m}$. Bagian ke enam terpadat pada meter ke 245 sampai meter ke 302 dengan kedalaman bervariasi dari 0 sampai $16 \mathrm{~m}$. Bagian ke tujuh terdapat pada meter ke 360 sampai meter ke 465 dengan kedalaman bervariasi antara $10 \mathrm{~m}$ sampai $32 \mathrm{~m}$.

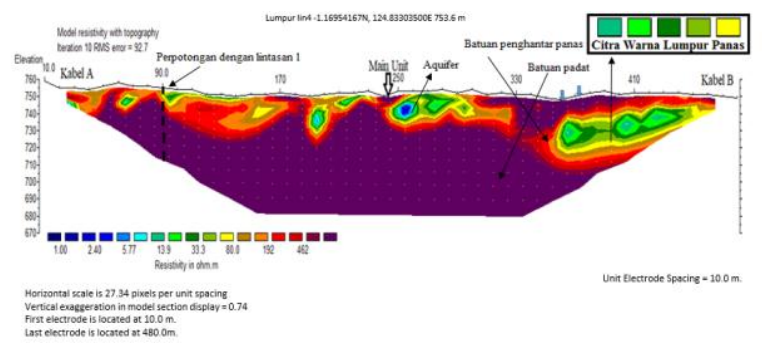

Gambar 6 Hasil identifikasi lintasan 4.

Dari penelitian yang telah dilakukan diketahui bahwa 4 daerah lintasan terdapat sebaran lumpur panas dan manifestasi yang ada juga sangat dekat dengan permukiman warga. Pembangunan yang didirikan di atas daerah sebaran lumpur dikhawatirkan suatu saat akan ambles (turun ke dalam tanah) karena lapisan tanah di permukaan tidak mampu menahan beban yang ada. Selain itu 
juga karena adanya pembangunan yang dapat menyumbat sebaran lumpur panas, karena energi panas bumi yang berada di bawah permukaan akan terus menerus berusaha keluar dan muncul sebagai manifestasi.

Berdasarkan hasil analisis sebaran lumpur panas diperoleh peta kerawanan daerah penelitian yang menunjukkan tingkat keamanan yang bisa digunakan sebagai referensi untuk membangun infrastruktur menggunakan Software Surfer 11 (Gambar 7).

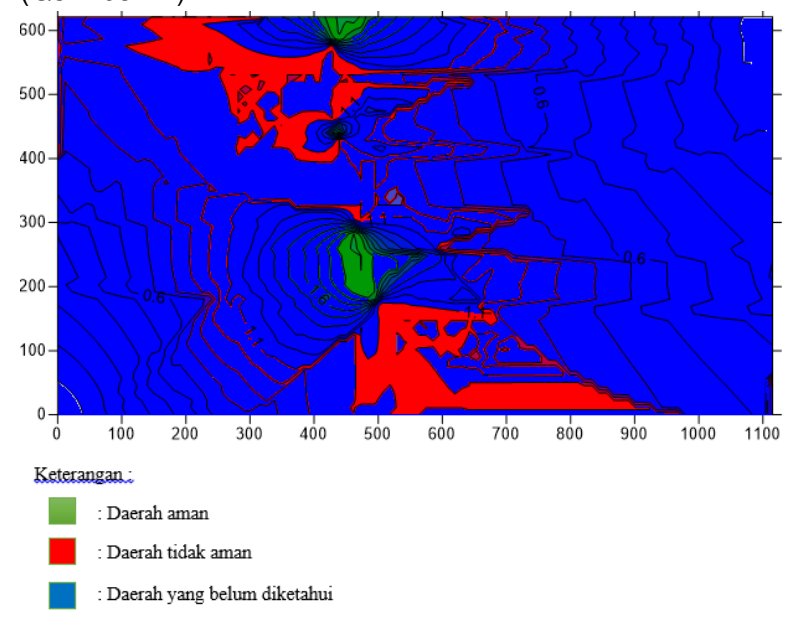

Gambar 7 Peta kontur kerawanan daerah penelitian. Citra warna biru menunjukkan daerah sekitar lokasi lintasan penelitian yaitu daerah yang belum diketahui kondisi di bawah permukaannya, citra warna hijau menunjukkan daerah yang aman untuk didirikan bangunan, citra warna merah menunjukkan daerah rawan karena terdapat sebaran lumpur dibawah permukaan dan tidak aman untuk didirikan bangunan.

Kesimpulan
Telah dilakukan penelitian di Desa Karumenga, Kecamatan Langowan Utara, Kabupaten Minahasa, Sulawesi Utara untuk mengetahui sebaran lumpur panas dari manifestasi energi panas bumi lumpur panas sebagai mitigasi bencana alam, diduga terdapat sebaran lumpur panas dengan interval resistivitas $13,9-80$.

Pada lintasan 1 lumpur panas terdapat di sepanjang lintasan dengan kedalaman bervariasi antara 0 sampai $32,5 \mathrm{~m}$. Lintasan 2 lumpur panas terdapat di sepanjang lintasan dengan kedalaman bervariasi antara 0 sampai $24,5 \mathrm{~m}$. Lintasan 3 lumpur panas terdapat di sepanjang lintasan dengan kedalaman bervariasi antara 0 sampai 33,5 $\mathrm{m}$. Lintasan 4 lumpur panas hanya terdapat di beberapa bagian, pertama terdapat pada meter ke 60 sampai meter ke 75 dengan kedalaman 4 sampai $11 \mathrm{~m}$, kedua terdapat pada meter ke 89 sampai 148 dengan kedalaman bervariasi antara 0 sampai 9,5 m, ketiga terdapat pada meter ke 150 sampai meter ke 165 dengan kedalaman 5 sampai $14 \mathrm{~m}$, keempat terdapat pada meter ke 190 sampai meter ke 201 dengan kedalaman bervariasi antara 4,5 m sampai $20,5 \mathrm{~m}$, kelima terdapat pada meter ke 205 sampai meter ke 230 dengan kedalaman bervariasi dari 0 sampai $6 \mathrm{~m}$, keenam terpadat pada meter ke 245 sampai meter ke 302 dengan kedalaman bervariasi dari 0 sampai $16 \mathrm{~m}$, ketujuh terdapat pada meter ke 360 sampai meter ke 465 dengan kedalaman bervariasi antara $10 \mathrm{~m}$ sampai $32 \mathrm{~m}$.

\section{Daftar Pustaka}

As'ari, dan Tongkukut, S. H. J. 2017. Identifikasi Potensi Cekungan Air Tanah di Universitas Sam Ratulangi Menggunakan Eksplorasi Geolistrik Tahanan Jenis. Jurnal MIPA Unsrat Online. 6(2): 29-31.

Basid, A., Andrini, N., dan Arfiyaningsih, S. 2014. Pendugaan Reservoir Sistem Panas Bumi dengan Menggunakan Survei Geolistrik Resistivitas dan Self Potensial. Jurnal Neutrino. 7: 58 - 59.

Ebrahimi, D., Nouraliee, J., dan Dashti, A. 2019. Inspecting Geothermal Prospects in anIntegrated Approach Within The West Azarbaijan Province of Iran. Journal Geothermics. 77: 224 - 235.

Faturahman, B. M. 2018. Konseptualisasi Mitigasi Bencana Melalui Perspektif Kebijakan Publik. Jurnal IImu Administrasi Publik. 3(2): 122 - 133.

Maarif, S., Pramono, R., Kinseng, A.R., dan Sunarti, E. 2012. Kontestasi Pengetahuan dan Pemaknaan Tentang Ancaman Bencana Alam. Jurnal Penanggulangan Bencana. 3(1): 1 - 13.

Pratama, W., Rustadi., dan Haerudin, N. 2019. Aplikasi Metode Geolistrik Resistivitas Konfigurasi Wenner-Schlumberger untuk Mengidentifikasi Litologi Batuan Bawah Permukaan dan Fluida Panas Bumi Way Ratai di Area Manifestasi Padok di Kecamatan Padang Cermin Kabupaten Pesawaran Provinsi Lampung. Jurnal Geofisika Eksplorasi. 5(1):3044.

Saptadji, N. M. 2010. Geothermal Education for Supporting Geothermal Development in Indonesia. Proceedings World Geothermal Congress. 1-6.

Wiranata, D., Natalisanto, A. I., Lazar, P. AD., dan Alam, F. 2018. Interpretasi Pola Sebaran Indikasi Mudvolcano di Suryanata Samarinda dengan Metode Geolistrik Konfigurasi WennerSchlumberger. Jurnal Geosains Kutai Basin. 1(2): 1- 7.

Wijaya, A. S. 2015. Aplikasi Metode Geolistrik Resistivitas Konfigurasi Wenner untuk Menentukan Struktur Tanah di Halaman Belakang SCC ITS Surabaya. Jurnal Fisika Indonesia. 19(55): 1 - 5.

Wildan, D., dan Wahyu, S. 2015. Studi Awal Karakteristik Pola Resistivitas Sistem Panas Bumi Temperatur Rendah-Menengah di Indonesia. Prosiding Seminar Nasional Fisika. 4: 31-36. 